\title{
擬似衛星による航空機進入時の測位精度の検討
}

\author{
坂井 丈泰* ・惟村 和宣* \\ 長岡、栄*・高橋美登里*·天井 治*
}

\section{A Study on the Positioning Accuracy for the Approaching Aircraft Using Pseudolites}

\author{
Takeyasu SAKAI, Kazunobu KOREMURA, \\ Sakae NAGAOKA, Midori TAKAHASHI and Osamu AMAI
}

\begin{abstract}
For a precision approach and landing system of aircraft using GPS, it is nessessary to improve the system performance such as positioning accuracy, integrity, continuity and availability. A possible way for improving the performance may be to use pseudolites (pseudo-satellites) located on the ground near airport in addition to ordinally GPS satellites.

In this paper, a qualitative simulation was carried out for evaluating positioning accuracy for the approaching aircraft using pseudolites together with the existing GPS satellites. Flight experimental data and artificial data on ranging measurement were used for the simulation.

The result shows that while the positioning accuracy strongly depends on relative location of pseudolites, GPS satellites and the aircraft, the accuracy can be improved by the utilization of pseudolites.
\end{abstract}

\section{1.はじめに}

GPSを利用した航空機用航法装置は、最近の大型機には標準装備される一方で多くの小型機にも搭載さ れ、参考計器として有効に活用されるようになってきている。将来的には、航空路上のみならず離陸から 進入着陸段階まで一貫してGPSを使用することが期待されており、現在そのための研究開発が各国で行わ れている。例光ば、GPSの精度や信頼性を補完する補強システムとして、米国のWAAS (wide area augmentation system)、および我が国のMSAS(MTSAT satellite based augmentation system)などの整 備が進められている。

WAASおよびMSASではRNP(required navigation performance ; 航法精度要件) カテゴリーI 相当 (決 心高度 $60[\mathrm{~m}]$ まで誘導可能。このとき、測位誤差を含むシステム䛊差の $95 \%$ 信頼区間が水平土37[m]、垂 直士 $12[\mathrm{~m}]$ の範囲にあること)までの精密進入が可能であるとされるが、さらに高いカテゴリーの誘導には 測位精度や信頼性が不足するといわれている。この精度向上のためには、搬送波の位相情報を利用するキ ネマティック方式が使用される可能性がある。また、空港周辺に擬似衛星 (pseudo-satellite ; pseudolite) と呼ばれる地上送信局を設置して、ここから送信される測距信号をも利用して測位演算を行う補強方式が 考えられている。これにより、GPSの弱点のひとつである垂直方向の測位精度が改善されるほか、信頼性 の向上も図れる可能性があると期待されている(1)。

擬似衛星はスタンフォード大学のParkinsonらによって研究開発が進められてきており、初期には擬似衛 星の最適配置に関する研究があるが(2)、近年はキネマティック測位方式における整数波数のアンビギュイテ

*正会員 運輸省電子航法研究所（元181-0004 三鷹市新川6-38-1） 
イを解くために擬似衛星を利用する方法を提案し、実験を行っている(3)(4)(5)。これは、ドップラー周波数を 測定することにより航空機が擬似衛星の上空を通過したことを検出し、このことを利用してアンビギュイ ティを精度良く決定するものである。また、国内においては、宇宙開発事業団および航空宇宙技術研究所 による宇宙往還機HOPEプロジェクトの一環として擬似衛星の利用が検討されている(6)。

我々は、航空機の進入着陸時に擬似衛星を使用することを想定して、測位精度や信頼性に及ぼす効果を シミュレーションにより計算している。今回は、擬似衛星を使用して測位計算を行った場合に測位精度が どのように改善されるか検討したので、その結果を報告する。

\section{2、擬似衛星による効果}

GPSの測位精度を左右する誤差要因にはさまざまなものがあるが、そのひとつは、測位計算に使用する 衛星と受信機の相対的位置関係である。GPSで測定される観測量は衛星と受信機の距離、すなわち擬似距

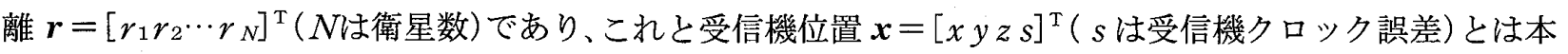
来注非線形方程式で関係づけられるものであるが、 $\boldsymbol{x}$ のまわりで適当な線形化を行えば次式で近似できる (8)。

$$
A d x=d r
$$

ここで、変換行列 $A$ は衛星と受信機の相対的位置関係により定まる。一般に、GPS衛星からの信号は水平 面よりも上方から到来するため、GPSでは垂直方向の測位精度が水平方向よりも低下するが、こ机は行列 $A の z$ に対応する成分の符号が限られることで説明できる。また、衛星と受信機の位置関係によっては変 換行列 $A$ の行ベクトル間の線形独立性が保たれず、極端な場合には解を一意に決定できない事態が生じう る(いわゆるDOP(dilution of precision)の大きい場合に相当する)。通常は測位計算に必要な衛星数は 4 個とされているが、同一軌道面の衛星や仰角の近い衛星を使うなどするとこの問題が顕在化することがあ り、上空に 4 個あれば常に正常に測位できるとは限らない。なお、キネマティック方式の場合には測定さ れる観測量は搬送波の位相積算值(衛星と受信機の距離に比例する)であり、受信機と基準局との位置関係 も問題に含まれる。また、DOPの值は式(1)の行列 $A$ により定まることを注意しておく(付録参照)。

こうした問題を解決する方法のひとつは、GPS衛星の数を増やして常に多数の衛星が見えるようにする ことである。しかし、GPSの衛星数にはPRNコードによる限度があるうえ、上空の衛星を増やすだけでは 行列 $A$ の性質に大きな変化はないため、垂直方向の測位精度が水平方向に比較して良くないという欠点は 改善されない。もうひとつの方法として、上空を飛行するGPS衛星だけではなく、地上にも衛星と同様の 測距信号を送信する無線局を配置するというのが擬似衛星のアイディアである。この方式では、利用可能 な衛星数が増える効果があるほか、擬似衛星が一般に航空機より下方に位置することから垂直方向の測位 精度が改善されると考えられている。なお、送信局を地上ではなく静止衛星軌道上に配置すると、GPS才 ーバーレイと呼ばれる方式になる。

擬似衛星方式では、測位精度の改善のほかにも、衛星数が増えることで冗長度が増し、信頼性が向上す るといら効果がある。しかも、地上に設置された固定送信局であるから、軌道上の衛星よりも故障率は低 いことが予想されるので、測位システム全体としての信頼性の向上に貢献する。

擬似衛星の実現上の問題点としては、受信機が複雑になるほかに、遠距離にあるGPS衛星との電界強度 の違いに起因する遠近問題 (near-far problem)がよく知られている。この問題について、Parkinsonらは 擬似衛星の送信電力を微弱にするかをたはパルス化するなどにより赛効的に覆域を小さくすることで解決 を図っている。

また、擬似衛星の配置は重要な問題である。例えば、測距のみによって測位を行らいわゆる距離方式で は、送信局間を結ぶ基線上で測位誤差が著しく増大する問題がよく知られており、GPS衛星に加えて擬似 衛星を使用する場合にはこの点にも十分な配慮が必要となる。技術的な問題以外にも、擬似衛星を含む狭 域補強システムのための地上施設は空港用地内に設置することが望ましいとの意見があり(米国FAAなど)、 擬似衛星の設置場所についてはさまざまな制約が課せられることとなろう。 


\section{3. シミュレーションの概要}

擬似衛星により測位精度がどのような影響を受 けるかを調べるため、計算機によるシミュレーシ ヨンを実施した。擬似衛星については人為的に作 成したデータを、上空の衛星については実際の航 空機による実験で取得したデータを使用すること とした。この飛行実験 ${ }^{(7)}$ は当所所有の実験用航空機 （ビーチクラフトB99）を使用して仙台空港にて寒施 したもので、実施時期は97年 2 月、受信機はNovAtel 社製RT20 (移動局)および3151R(基地局)である。 なお、本実験は進入着陸に関する目的のために行 われたものではないため、進入時の飛行経路につ いては特段の配虑はされておらず、手動操縦によ り適宜着陸している。

実験機の飛行コースを、図 1 (a) に示す。図の 座標軸は、 $X$ 軸を滑走路中心線(東が正方向)、 $Z$ 軸を垂直方向にとり、 $Y$ 軸はこれらと右手系をつ くるよう設定した(図 2 も参照)。原点は滑走路東 端スレッショルド(TH27)である。また、実験中の 衛星の配置は ( b ) のとおりであった。この図は、 受信機位置からの衛星の見え方を仰角・方位角で 表示しているもので、中心からの距離が仰角を(中 心が仰角90[deg]、周囲が仰角 0 [deg] に対応する)、 方位はそのまま方位角を表している。仰角が負の 場合には絶対值で表示する。

実験機は滑走路東側の約 $10[\mathrm{~km}]$ 地点から降下し ながら進入し、TH27の後方 $500[\mathrm{~m}]$ 付近で接地、 しばらく滑走したあと誘導路にロールアウトする。 実験中は図 1 (b)のように常時 7 個以上の衛星が 見えており、（a）のコースはこの7 個の衛星を使 用してキネマティック方式により計算したもので

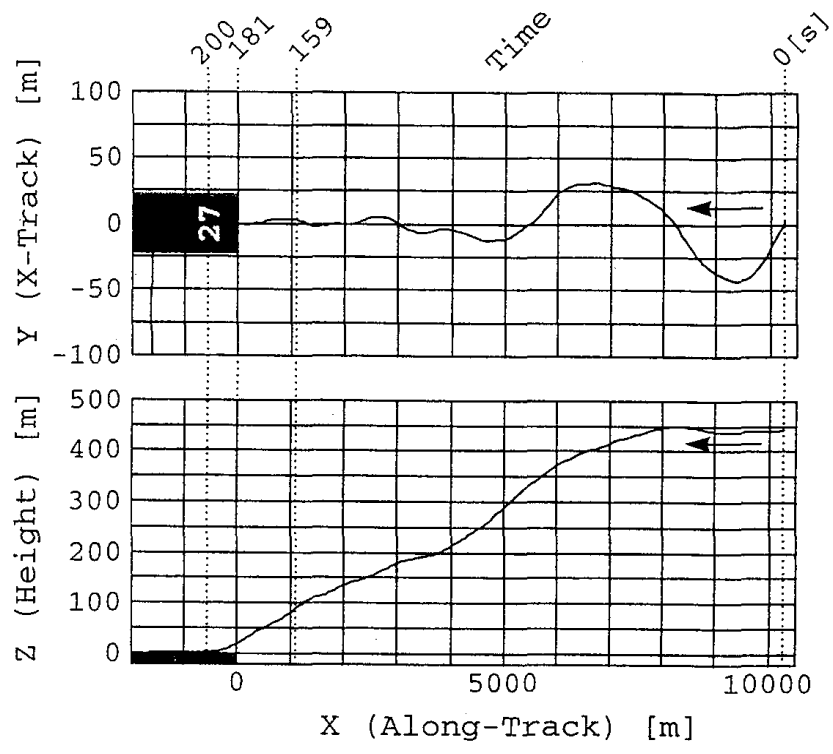

（a）基準コース

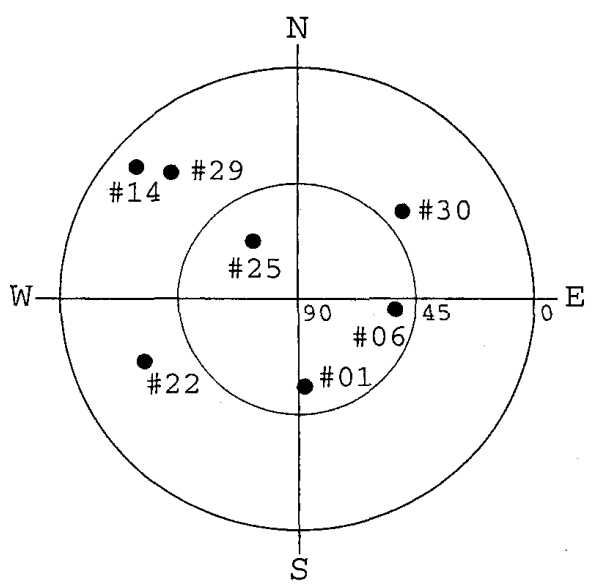

（b）衛星配置

図 1 シミュレーションで比較の対象とした基準コース

ある。この際の衛星位置については精密軌道暦を併用している。以下のシミュレーションではこの飛行コ 一スを比較の対象とし、基準コースと呼ぶこととする。

図 1 ( b ) の衛星配置では、DOPの平均值はPDOP=2.6, $\mathrm{HDOP}=1.13, \mathrm{VDOP}=2.35$ であった。なお、 本論文で表示しているDOPの值は通常のコード方式におけるものではなく、二重位相差 ${ }^{(9)}$ を用いるキネマ ティック方式の場合における值としている。これは、二重位相差を使用する場合には式(1)の変換行列 $A$ の 内容がコード方式とは変わってくるため、通常のDOP值を表示するよりも適当と考えたことによる(詳細は 付録を参照。ただし、少なくとも本論文中の計算においては、両者にさほどの違いは認められなかった)。 また、二重位相差を求める衛星対については、常にその片方がPRN\# 01 衛星となるように選んだ。

シミュレーションに際して想定した擬似衛星の配置を図 2 に示す。擬似衛星の配置は 2 パターンを考え、 擬似衛星なしの場合も含めて 3 パターンについて計算を行った。

パターン A：擬似衛星なし

パターンB：1個の擬似衛星をILSミドルマーカ (MM)アンテナ位置に設置(図 2 ( a ) )

パターンC : ミドルマーカの南北 $300 \mathrm{~m}$ の位置に各1個と、滑走路西側延長上(ILSローカライザ位置)に

1 個、合計 3 個を設置 (図 $2(\mathrm{~b})$ )

パターンB の配置は、送信局を結ぶ基線上における測位精度の低下を確認することを狙い、擬似衛星の 
直上付近を実験機が通過するように選んだことに よる。またパターンCでは、より実用に近い状況 を想定して 3 個の擬似衛星を配置した。ILSミドル マーカおよびローカライザの位置を基礎にしたの は、空港用地内に設置するという制約を想定した ためである。

シミュレーションにあたり擬似衛星の送信して くる測距信号の位相積算値データを作成する必要 があるが、このために前述の基準コースを飛行し

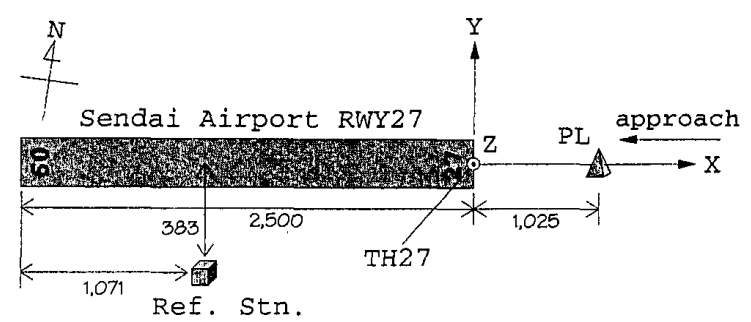
た場合に得られるべき二重位相差を計算し、これ に標準偏差 $\sigma=0.02[\mathrm{cycles}] \approx 4[\mathrm{~mm}]$ のガウス雑音 を加えたものを与えた。この $\sigma$ の值は、基準コー スの計算で得られた二重位相差の残差の分布より、 バイアス成分を除いて決めたものである。

その他、擬似衛星に関する仮定を以下に列挙す る。

1. 送信アンテナは海抜 $5[\mathrm{~m}]$ の高さに設置。

2. 搬送波周波数はL1信号と同じ1575.42[MHz] とする。

3. 擬似衛星の内部クロックは、正確にGPS time に同期している。

4. 送信アンテナは無指向性とする。

5. 寨験機の受信アンテナも無指向性とし、GPS受信アンテナと擬似衛星からの信号の受信アンテナの設 置位置の相違に起因する問題はここでは考慮しない。

6. 基準局とのデータリンクの伝送遅延は無視する。

このうち最も現実的でない仮定は 5 ，と思われ、上方および下方から到来する測距信号を受信するために 別々のアンテナが必要となることは、実は擬似衛星を使用する場合の欠点のひとつである。また、6．は 現状がオフライン処理によるシミュレーションであることを指しているが、実際の飛行ではもちろんリア ルタイム処理が必要となるので、基準局における処理時間およびデータ伝送時間を考慮する必要が生じる。

\section{4. 計算結果}

前節に述ベたシミュレーション条件に基づいて、擬似衛星のない場合も含めて 3 パターンの配置につい てどのような測位結果が得られるか計算を行った。この際、基準コースからのずれを測位誤差として観測 することにした。本来はシミュレーション対象よりもさらに高精度の測位方式による結果を評価基準とし て用いるのが通常の方法であるが、今回は評価対象がキネマティック測位による計算結果であり、これ以 上の測位精度を持つ測位装置が今のところ存在しない。このため、7 衛星の精密軌道暦による測位結果(今 のところもっとも正確と思われる)を基準コースとして採用し、比較対象のほうの衛星数を少なくすること で、相対的に高い精度の評価基準を得ることとした。基準コースとの差ができるだけ顕著に現れるように、 この比較対象のほうの衛星数は4個に限定した。これはGPS衛星と擬似衛星をあわせて 4 個であって、使用 する衛星については基準コースを計算した際の二重位相差の残差の傾向を見て偏らないように選択した(DOP の良否などにより選択したものではない)。シミュレーションのおおまかな流れを、図 3 に示す。

また、以下の計算結果については、基準コースの算出経緯のほかにも、擬似衛星の測距信号にはバイア ス性のノイズが含まれていないことにも注意しなければならない。このため、測位䛊差に含まれるバイア ス性の成分は少なくなっている(パターンB)か、または消失している(パターンC)ので、測位誤差そのも のは直接比較できず、その傾向を比較検討することになる。バイアス成分の取扱いは、今後検討が必要な 課題のひとつである。 
4.1 擬似衛星なしの場合(パタ ーンA)

まず、パターンA、すなわち擬 似衛星のない場合の計算結果を、

図 4 に示す。(a)の横軸はGPS時 刻で255秒間、縦軸は $X, Y, Z$ 各軸 の基準コースに対する誤差で、(b) は衛星配置を示している。 $X, Y$ 軸 方向にはほとんど誤差はみられな いが、 $Z$ 軸方向 (垂直方向) に20[cm] 程度までの差を生じている。この 誤差は時間の経過とともに減少し ていることから、計算開始時点に おける実験機位置が基準局から約 $12[\mathrm{~km}]$ と遠距離であり、計算が進 むにつれて基準局に近づいている ことによるものと思われる。なお、 このときのDOPの平均值は

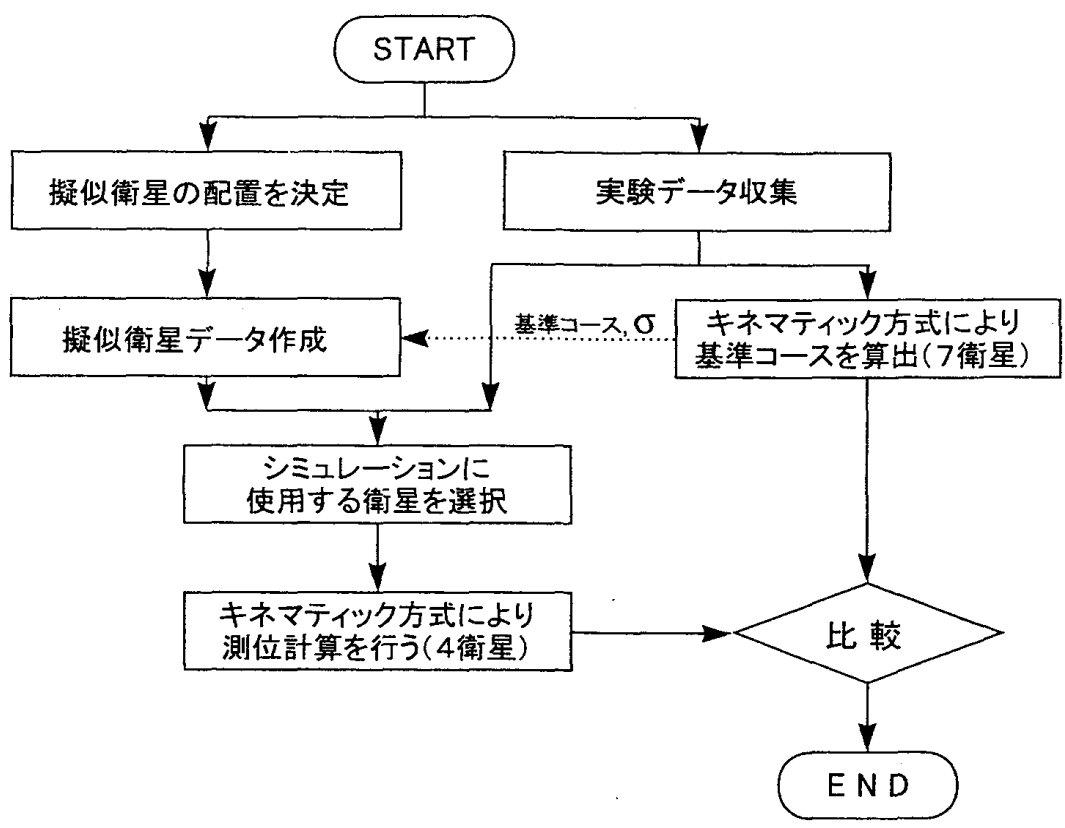
$\mathrm{PDOP}=4.79, \mathrm{HDOP}=2.54$, $\mathrm{VDOP}=4.05$ 、ほとんど変化はなかった。

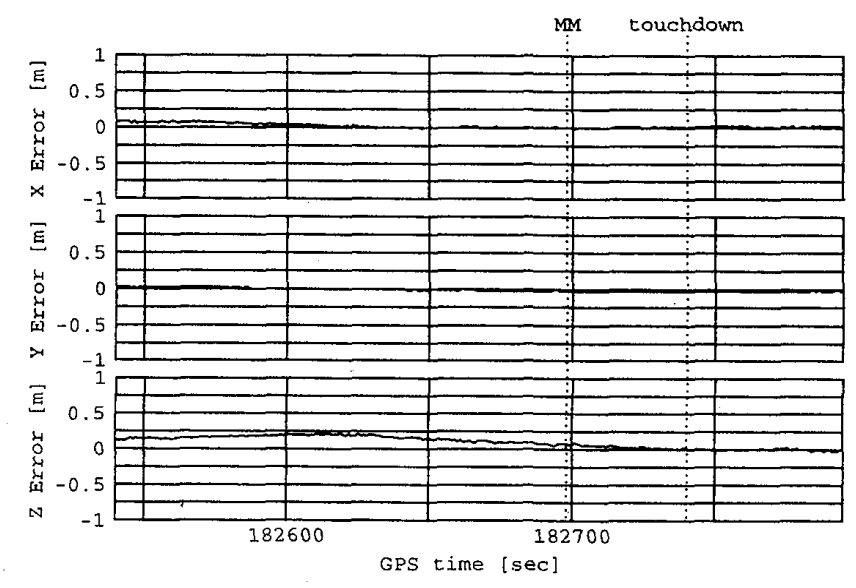

(a) 測位誤差

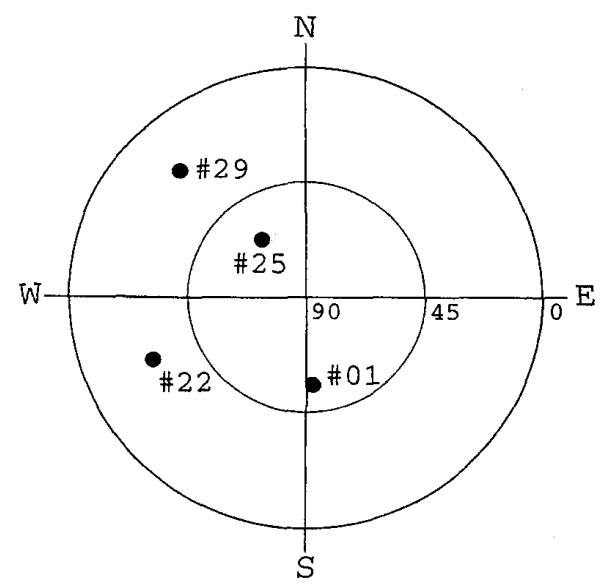

（b） 衛星配置

図 4 擬似衛星を使用しない場合(パターンA)の計算結果

\subsection{1 個の擬似衛星を使用 (パターン B)}

次に、GPS衛星 3 個と擬似衛星 1 個を用いた、パターンB の計算結果の例を図 5 に示す。実験機が擬似 衛星商上空を通過(最接近は $182,699[\mathrm{~s}])$ する数秒前 $(182,695[\mathrm{~s}])$ に誤差が大きく発散し、なおかつ誤差の 符号が突然変わるといら特徴がみられる。これは、航空機が擬似衛星に接近し、さらに上空を通過するこ とで、これらの幾何学的位置関係が大きく変わるのが原因である。

すなわち、誤差の符号が変わる前後での実験機と擬似衛星の幾何学的位置関係をよく調べると、符号変 化前には測位計算の際に擬似衛星に関してできる回転双曲面(双曲線航法にお打る位置の線に相当するもの) (9)の下側を実験機が飛行しているのに対して、符号変化後は同じく上側に位置している、といら違いがある ことがわかる。図6のように、回転双曲面の下側から上側に位置関係が移ることにより、測位誤差の現れ かたが逆になり、符号が突然变わるものと思われる。図 5 (b)によれば、最初は西の方向に見えていた擬 似衛星が次第に接近し、実験機のほぼ真下を通って東に遠ざかっていく様子がわかる。なお、（b）は1秒每 


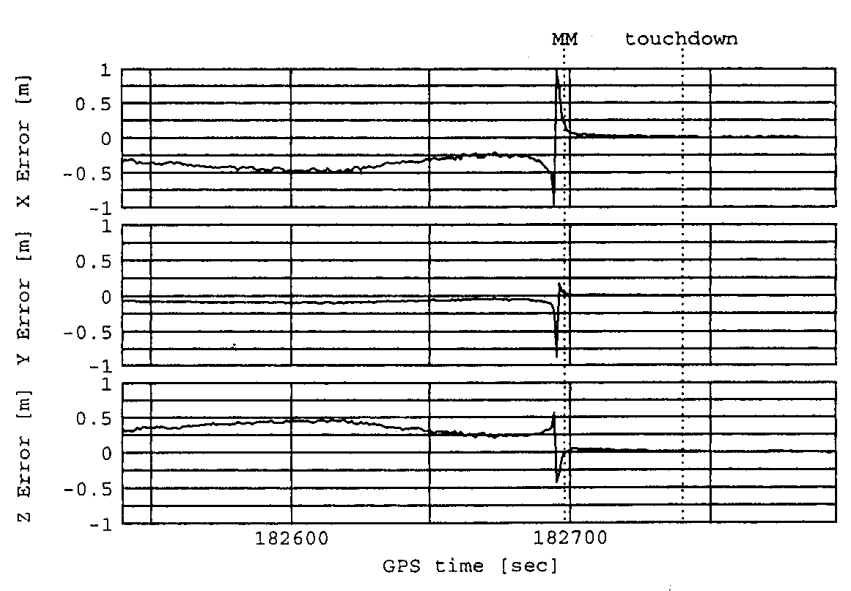

（a） 測位誤差

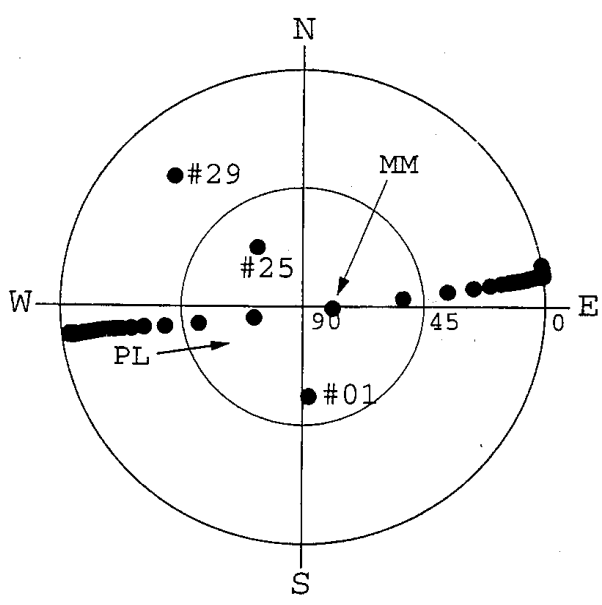

（b）衛星配置

図 5 1個の擬似衛星を使用する場合(パターンB)の計算結果

にプロットしてある(図 7 も同様)。

この例のように、擬似衛星を使用する場合にむ、やはり送 信局間を結ぶ基線上で測位精度が低下する現象は避けられな いことがわかる。こうした位置関係にならないように、進入 コースの設定および擬似衛星の配置には十分な配慮が必要で ある。

また、擬似衛星の手前では $X, Z$ 軸で $50[\mathrm{~cm}] 、 Y$ 軸で $10[\mathrm{~cm}]$ 程度までの誤差が見られるが、上空通過後は小さな值に収ま っていることもわかる。航空機の進入着陸にあたってはミド

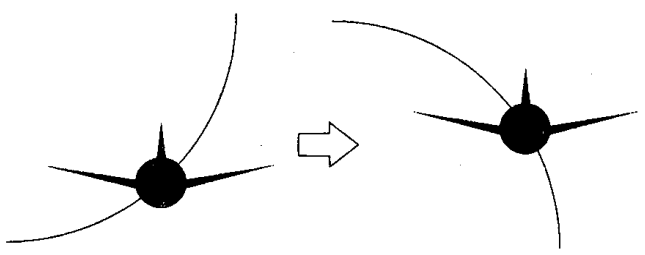

図 6 実験機が回転双曲面の下側から上 側に移る様子(前方から見た図) ルマーカ通過から接地直前までの時間帯が最も精度・信頼性 を要する局面であるから、このような性質は重要なものである。

\subsection{3 個の擬似衛星を使用 (パターンC)}

擬似衛星を 3 個に增やしたパターンCでは、図 7 のような計算結果が得られた。パターン $\mathrm{B} に$ 比ベて誤 差のバイアス成分が減少しているが、これは擬似衛星に与える二重位相差データに加えた雑音がバイアス を含まないためと思わ扎る。誤差のばらつき成分については、初めのうちは大きいが、2 個の擬似衛星に 近づくにつれて減少していき、それらの間を通過したあとは小さな值に落ち着いていることがわかる。実

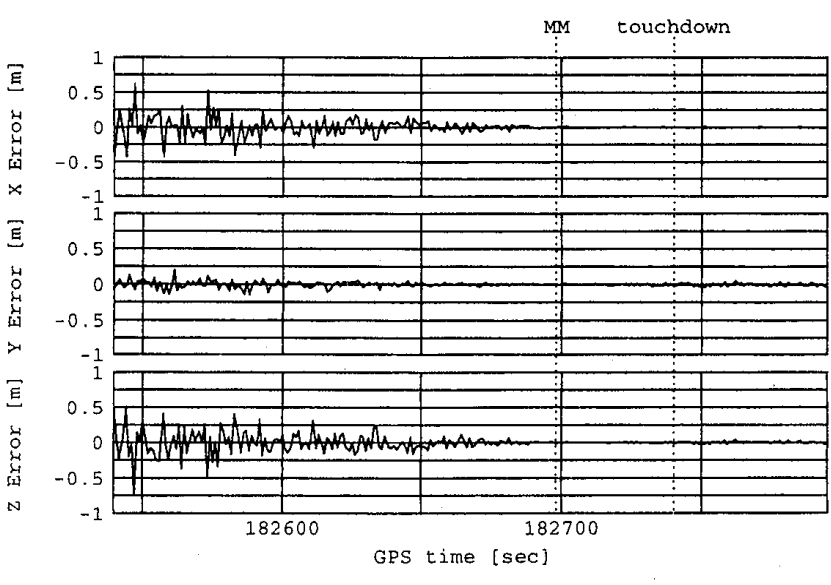

（a） 測位誤差

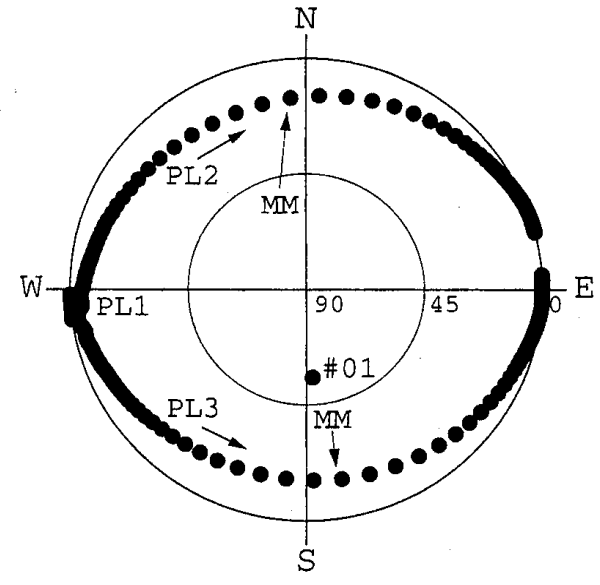

(b) 衛星配置

図 73 個の擬似衛星を使用する場合(パターンC)の計算結果 
験機と擬似衛星の相対的位置関係は (b)のとおり で、擬似衛星PL1は常に西の方向にあり位置を大き く変えないが、PL2、PL3は西からそれぞれ実験機 の北および南側を低仰角で通り過ぎ、やはり東に 遠ざかっていく様子がわかる。

\subsection{DOPの時間的変化について}

擬似衛星がある場合には、短時間でも移動局か ら見た衛星配置が大きく変わるため、測位精度も 急激に変化する。このことを確かめるためにDOP の時間的変化を調べてみた結果を、図 8 に示す (参 考までに、コード方式の場合のDOPを破線で示し た)。

(a) は擬似衛星のないパターンAにおけるDOP の時間的変化の様子であり、各衛星と実験機の位 置関係が大きく変化しないため、DOPはほぼ一定 の值を保っている。

(b) はパターンBにおけるDOPの変化の様子で、 変化する範团はPDOP $=3.0 \sim \infty, \mathrm{HDOP}=1.8 \sim \infty$, $\mathrm{VDOP}=0.84 \sim \infty$ であった。PDOP、HDOPの最 小值は接地後に現れているのに対して、VDOPの 最小值だけは擬似衛星の上空を通過する直前 $(182,698$ [s])に得られていることより、擬似衛星により垂 直方向の測位精度を改善する効果があるものと思 われる。

(c ) はパターンCのものであり、DOPの值は $\mathrm{PDOP}=1.41 \sim 117.0, \mathrm{HDOP}=1.18 \sim 80.4$, $\mathrm{VDOP}=0.73 \sim 85.0$ の範囲にあった。2個の擬似衛 星の間を通過する際にVDOPが最小值となり、そ れより数秒遅れてPDOP、HDOPが最小值に達す る。

図 8 と図 $4 \sim 7$ との比較より、測位精度とDOP との間にはよい相関が認められ、DOPの大きい部 分では測位結果の精度が悪くなる、といら対応関 係があることがわかる。これは擬似衛星のないコ 一ド方式の場合と同様であり、DOPが測位精度の 予測に有効であることが予想される。

\section{5. むすび}

航空機の着陸進入時について、擬似衛星を導入 した場合のシミュレーションを行い、測位精度の 傾向を調べた。この結果、垂直方向のDOP(VDOP) が改善される場合があるなど、測位精度に関する 擬似衛星の有効性を確認できた。

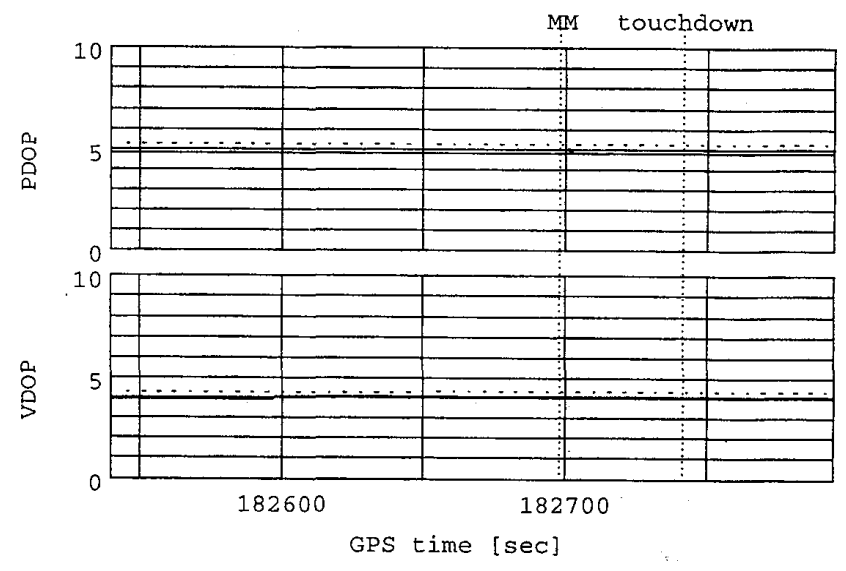

(a) パターンA

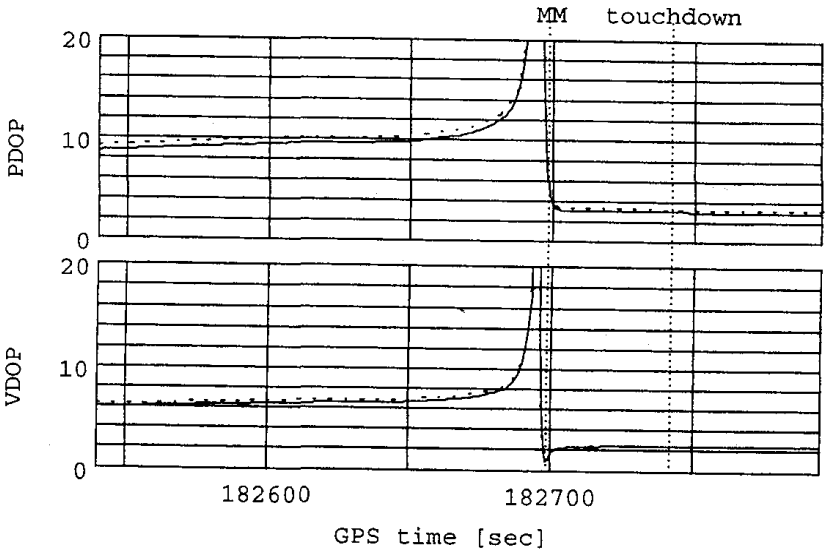

(b) パターンB

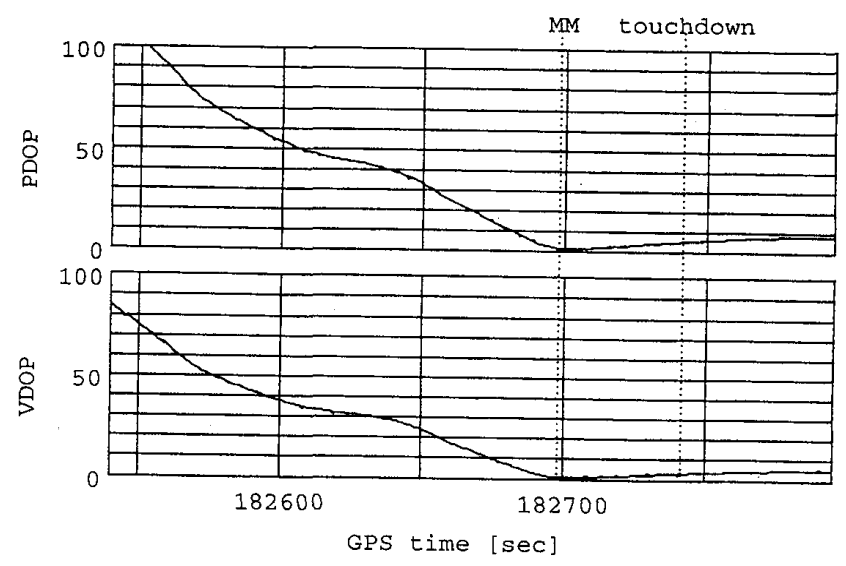

(c) パターンC

図 8 擬似衛星使用時のDOPの時間的変化の様子(破 線はコード方式の場合のDOP)

測位精度とDOPとの間には相関がみられ、DOPにより測位精度を間接的に評価することも可能と思われ る。すなわち、進入コース近傍の全域にわたってDOPを評価し、常にDOPが良好となるような擬似衛星配 置を選択すれば、幾何学的位置関係が原因で測位精度が低下することは生じないと考えられる。 
ただし、擬似衛星を進入コースの真下に置くような配置は、一時的にDOPの急激な变化をもたらし、測 位精度が低下する場合がある。もちろん実用にあたってはこうした配置は避けなければならないが、具体 的にどのような配置が望ましいかについてはさらに検討が必要である。

今後の課題としては、この配置の問題に加えて、測位システムとしての信頼性に及ぼす効果について検 討していく予定である。この際のシミュレーションの実施にあたっては、擬似衛星に関する位相データに 含まれるべきバイアスの取扱いに一考が必要である。また、上空のGPS衛星と擬似衛星のために複数のア ンテナが必要となるなど、擬似衛星に特有の問題点をいくつか把握できたので、これらについても検討を 加えたいと考えている。

最後に、飛行実験の際に協力をいただいた当所航空施設部加来主任研究官に感謝いたします。

\section{参 考 文 献}

（1）惟村和宣：“航空分野に㧍ける利用”，シンポジウムGPS/DGPS利用技術の展望，pp.95-113，1996.

(2) B. Parkinson and K. Fitzgibbon : "Optimal Locations of Pseudolites for Differential GPS", Navigation : Journal of the Institute of Navigation, vol.33, no.4, pp.259-283, Winter 1986-87.

(3) C. Cohen, B. Pervan, D. Lawrence, H. Cobb, J. Powell and B. Parkinson : "Real-Time Flight Test Evaluation of the GPS Marker Beacon Concept for Category III Kinematic GPS Precision Landing", ION GPS-93, pp.841-849, Salt Lake City, Sept. 1993.

(4) C. Cohen, D. Lawrence, B. Pervan, H. Cobb, A. Barrows, J. Powell and B. Parkinson : "Flight Test Results of Autocoupled Approaches Using GPS and Integrity Beacons”, ION GPS-94, pp.1145-1153, Salt Lake City, Sept. 1994.

(5) H. Cobb, D. Lawrence, B. Pervan, C. Cohen, J. Powell and B. Parkinson : "Precision Landing Tests with Improved Integrity Beacon Pseudolites", ION GPS-95, pp.827-833, 1995.

（6）宮沢与和・泉 達司：“ALFLEXの航法誘導制御", Navigation：日本航海学会誌, no.132, pp.59-69, 1997.

（7）長岡 栄・高橋美登里・天井 治：“キネマティックGPSを用いた測高レーダの校正のための飛行実験”, 日本航海学会論文集, vol.97, pp.7-14, 1997.

（8）日本測地学会編著：新訂版GPS一人工衛星による精密測位システムー, pp.124-126, 日本測量協会, 1989.

(9) 同じく pp.148-156.

\section{[付＼cjkstart録］ 測位計算の概略とDOPについて}

GPSにおける測位解は、測位に使用する衛星を中心とする球面(二重位相差を用いるキネマティック方式 の場合は衛星位置を焦点とする回転双曲面)の交点として得られる。この問題は非線形方程式として記述さ れ、一般的には本文中の式(1)のように線形化したうえで逐次近似法により解を得る。

具体的には、コード方式における行列 $A^{C}$ は、 $N=4$ の場合

$$
A^{C}=\left(\begin{array}{llll}
\alpha_{1}^{C} & \beta_{1}^{c} & \gamma_{1}^{C} & -1 \\
\alpha_{2}^{C} & \beta_{2}^{C} & \gamma_{2}^{C} & -1 \\
\alpha_{3}^{C} & \beta_{3}^{C} & \gamma_{3}^{C} & -1 \\
\alpha_{4}^{C} & \beta_{4}^{C} & \gamma_{4}^{C} & -1
\end{array}\right)
$$

という形をしている。ここで、 $\boldsymbol{x}$ を原点とする地平座標系 ( $z$ 軸が地面に垂直な座標系) における衛星 $i$ の 位置を $\left(x_{i}, y_{i}, z_{i}\right) 、 i=1, \cdots, N$ 、受信機との距離を $\rho_{i}$ と表せば、

$$
\alpha_{i}^{C}=\frac{\partial \rho_{i}}{\partial x}=-x_{i} / \rho_{i}, \quad \beta{ }_{i}^{C}=\frac{\partial \rho_{i}}{\partial y}=-y_{i} / \rho_{i}, \quad \gamma{ }_{i}^{C}=\frac{\partial \rho_{i}}{\partial z}=-z_{i} / \rho_{i}
$$

である。2 節で述べたように、GPSで垂直方向の測位精度が水平方向よりも低下する理由は、 $\gamma_{i}^{C}$ の符号が 負に限られるためである。 
キネマティック方式の場合には、二重位相差を得た段階で受信機クロック誤差に関する項が消去されて

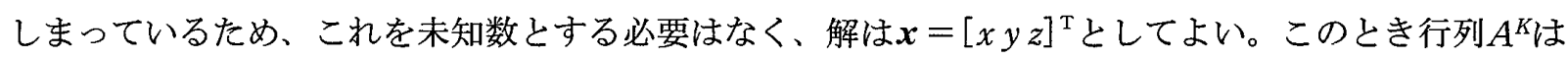

$$
A^{K}=\left(\begin{array}{lll}
\alpha_{1}^{K} & \beta_{1}^{K} & \gamma_{1}^{K} \\
\alpha_{2}^{K} & \beta_{2}^{K} & \gamma_{2}^{K} \\
\alpha_{3}^{K} & \beta_{3}^{K} & \gamma_{3}^{K}
\end{array}\right)
$$

となっており、係数は

$$
\begin{aligned}
& \alpha \underset{i}{K}=\frac{\partial \rho_{i}}{\partial x}-\frac{\partial \rho_{N}}{\partial x}=-x_{i} / \rho_{i}+x_{N} / \rho_{N} \\
& \beta{ }_{i}^{K}=\frac{\partial \rho_{i}}{\partial y}-\frac{\partial \rho_{N}}{\partial y}=-y_{i} / \rho_{i}+y_{N} / \rho_{N} \\
& \gamma \underset{i}{K}=\frac{\partial \rho_{i}}{\partial z}-\frac{\partial \rho_{N}}{\partial z}=-z_{i} / \rho_{i}+z_{N} / \rho_{N}
\end{aligned}
$$

と書くことができる $(i=1, \cdots, N-1$ 、二重位相差はすべて衛星 $N$ との間で求めるものとする)。

式(1)はまた、観測值 $\boldsymbol{r}$ に含まれる䛊差成分が解 $\boldsymbol{x}$ にどのような影響を与えるかをも表しており、この性 質を利用しておおまかな測位誤差を示すのがDOPと呼ばれる值である。本論文中で表示したDOPは、

$$
\left(A^{C^{\mathrm{T}}} A^{C}\right)^{-1}=\left(\begin{array}{cccc}
\sigma_{x x}^{2} & \cdots & \cdots & \cdots \\
\cdots & \sigma_{y y}^{2} & \cdots & \cdots \\
\cdots & \cdots & \sigma_{z z}^{2} & \cdots \\
\cdots & \cdots & \cdots & \sigma_{t t}^{2}
\end{array}\right), \quad\left(A^{K^{\mathrm{T}}} A^{K}\right)^{-1}=\left(\begin{array}{ccc}
\sigma_{x x}^{2} & \cdots & \cdots \\
\cdots & \sigma_{y y}^{2} & \cdots \\
\cdots & \cdots & \sigma_{z z}^{2}
\end{array}\right)
$$

の対角要素を用いて

$$
\begin{aligned}
& P D O P=\sqrt{\sigma_{x x}^{2}+\sigma_{y y}^{2}+\sigma_{z z}^{2}} \\
& H D O P=\sqrt{\sigma_{x x}^{2}+\sigma_{y y}^{2}} \\
& V D O P=\sigma_{z z}
\end{aligned}
$$

のように計算した(これはコード方式では一般的な定義である)。測位結果の誤差を総合的に表すのがPDOP $(\mathrm{P}=$ Position) であり、PDOPはさらに、水平方向を表すHDOP $(\mathrm{H}=$ Horiozontal $)$ と垂直方向を表すVDOP (V=Vertical) とに分けることができる。ただし、HDOPおよびVDOPの計算に際しては、測点位置におけ る地平座標系を使用しなければならない点に注意が必要である。

\section{質 疑 応 答}

林 尚吾(東京商船大学)：擬似衛星を着陸コースの真下に設置することの不具合はよく理解できた。欧米 の論文等では擬似衛星を山頂に設置する例を見かけるが、例えば富士山頂に設置するというような例は 検討しているか。

坂井丈泰：擬似衛星の配置も課題のひとつと考えておりますので、今後検討していきたいと思います。 